\title{
XVI International Congress of Metallurgy and Materials SAM-CONAMET 2016 and Symposium Materials and Technologies for the Metalmechanic and Aerospace Industry
}

Marcos Iván Oliva ${ }^{1}$

\author{
${ }^{1}$ Associate professor \\ National University of Córdoba, Córdoba, Argentina. \\ Faculty of Mathematics Astronomy Physics and Computing \\ Institute of Physics Enrique Gaviola - CONICET - UNC \\ e-mail: omarcos@famaf.unc.edu.ar
}

The sixteenth edition of the International Congress of Metallurgy and Materials SAM-CONAMET, in conjunction with the first edition of the Symposium "Materials and Technologies for the Metalmechanic and Aerospace Industry", was developed between November 22 and 25, 2016 at the Universidad Tecnológica Nacional - Facultad Regional Córdoba, Córdoba, Argentina.

The SAM-CONAMET congress is one of the largest Ibero-American conferences on research, technology and applications of Materials Science. The same is done alternately in Argentina and Chile, called CONAMET-SAM when it is developed in Chile. Its origin goes back to the year 2001 when the annual meetings that the Argentinean Association of Materials (SAM) and the Chilean Society of Metallurgy and Materials (SOCHIM) were carrying out independently. It aims to bring together the Material Science community to establish contacts, improve integration and present and discuss critically the latest developments and innovations in this area. It constitutes, therefore, an update on the latest research on new materials, allowing to know the current situation of the research that is developed in the field, following the SAM foundational spirit [1].

Various regions of the Province of Córdoba, especially its metropolitan area, are a development pole for different types of industries closely related to the application of materials [2, 3]. The aerospace industry with the construction of aircraft [4], rockets [5] and satellites [6], the Metal-mechanic industry with the manufacture of trucks, cars and components [3], as well as the whole industry related to the obtaining of machinery and equipment for the agricultural industry [7] can be highlighted. Thus, the Symposium "Materials and Technologies for the Metalmechanic and Aerospace Industry", in its first edition, aimed to disseminate materials-related topics, focusing mainly on the processes of procurement, transformation and final disposal, as well as applicable technologies In the metalmechanic and aerospace industry.

As a whole, congress and symposium managed to concentrate the presentation of six hundred (600) works and the participation of more than five hundred (500) assistants of broad sectors of industry, education and research, both basic and applied, in Materials Science. Promoting an adequate scope for the diffusion and access to technological knowledge, promoting also the strengthening and expansion of the network of contacts between professionals of related themes.

\section{BIBLIOGRAFíA}

[1] FERNANDEZ MOLINA, C.E. "Orígenes y Evolución de la Sociedad Argentina de Metales", Metalurgia Moderna v.1 n. 1pág. 9-10, 1959.

[2] FERRERO, F. "Localización industrial en la Provincia de Córdoba", Revista de Economía y Estadísca Tercera Época, v. 8, n. 2, pp. 7-42, 1964.

[3] FERRERO, F. "Localización industrial en la Provincia de Córdoba", Revista de Economía y Estadística Tercera Época, v. 8, n. 2, pp. 7-42, 1964.

[4] BUFFALO, L. "Estudios Socioterritoriales", Revista de Geografía, n. 16, v. 1, pág. 111-138, 2014.

[5] GOLDES, G. www.lavoz.com.ar/columna/cinco-decadas-cohetes-nacionales.

[6] DANIEL E. ARIAS. “Los satélites ARSAT-1, 2 y3 y la firma que crece detrás”, U-238 Tecnología Nu- 
clear para el Desarrollo, año 3 n. 13 p 26 -29, 2014.

[7] BRAGACHINI, M., MÉNDEZ, A., SCARAMUZZA, F. INTA Manfredi, Córdoba 2011. 